\title{
Indigenous Utilization and Management of Useful Plants in and around Awash National Park, Ethiopia
}

\begin{abstract}
Keywords: Awash National Park; Ethnobotany; Indigenous knowledge; Useful plants; Utilization

\section{Abstract}

An ethnobotanical study in and around Awash National Park with special emphasis on useful plants was conducted from September 2014 to August 2015. The study was aimed at documenting the indigenous knowledge of people on utilization and maintenance of cultural significance useful plants in their pastoral areas. Sixty-two useful plants belonging to 49 genera and 31 families were collected and identified from the study area. Most of plants investigated in the area have multiple uses which accounted to 54 species $(87 \%$ of total plants). Totally, five useful plant categories were identified, including 35 medicinal species, 22 wild edible species, 39 forage species, 17 species for cosmetics and beauty and 45 species used for construction, fuel and firewood. In preference ranking of medicinal plants, Acacia negrii was ranked first followed by Acacia senegal to treat wound. Analysis of direct matrix ranking on multiple uses of seven species revealed that Boswellia microphylla, Ziziphus spina-christi and Balanites aegyptiaca were reported to be the most important and intensively used species in the community. Informant consensus factor analysis showed that construction, fuel and charcoal $(72 \%)$ and wild edible plants $(71 \%)$ had high informant agreement. In plant species level, informant consensus was higher for Rostraria cristata which was cited by $91.9 \%$ used for forages followed by Grewia villosa $(72.5 \%)$ and Lawsonia inermis (62.9\%) for different cosmetics in the society. In and around the Awash National Park, useful plants were facing threats in their natural habitats from various human activities. Population pressure followed by drought and agricultural expansion was found as the major threatening factors. The urgent actions are needed to conserve such vital plant resources. Further analysis of pharmaceutical and nutritional values of plants should be evaluated to optimize their wise use in the future.
\end{abstract}

\section{Introduction}

The history of indigenous people depending on plants and utilization, physical and social environment shapes plant use and plant-human interaction. Ethnobotany is the study of this plant human interrelationship embedded in dynamic ecosystem of natural and social components [1-4]. The role of plants reflects their biological and physical properties. The natural, anthropological, environmental and genetic factors limited responses of plants to human's need. In the beginning, plant use was restricted to food, medicine and shelter, but later human beings have explored the potential of plants for a number of other purposes. Hence, human's dependency on plants has increased both directly and indirectly [2].

Human beings depend mainly on plants and to a less extent on animals for the basic requirements of their existence [3]. The indispensable dependence of humans on plants for their livelihoods primarily started with domestication and can be dated back to ten thousand years ago [4]. The collection of useful plants around homes

\section{\& Journal of Plant Biology \& Soil Health}

\section{Dinkissa Beche ${ }^{1}$, Getaneh Gebeyehu ${ }^{2 *}$ and Kebenu} Feyisa $^{3}$

${ }^{1}$ Department of Biology, Samara University, Semera, Ethiopia ${ }^{2}$ Department of Biology, Assosa University, Assosa, Ethiopia

${ }^{3}$ Department of Natural Resource Management, Samara University, Semera, Ethiopia

\section{Address for Correspondence}

Getaneh Gebeyehu, Department of Biology, Assosa University, P.O. Box 18, Assosa, Ethiopia, Tel: 0910176047; E-mail: getanehgebeyehu@yahoo.com

\section{Submission: 07 April, 2016}

Accepted: 27 May, 2016

Published: 04 June, 2016

Copyright: ๑ 2016 Gebeyehu G, et al. This is an open access article distributed under the Creative Commons Attribution License, which permits unrestricted use, distribution, and reproduction in any medium, provided the original work is properly cited.

Reviewed \& Approved by: Dr. Jiansheng Liang, Department of Biology, South University of Science and Technology of China, China

Dr. Daike Tian, Shanghai Chenshan Plant Science Research Center of CAS, Shanghai Chenshan Botanical Garden, China.

must have gradually lead to small scale plants, whose continued intensification resulted in the emergence of full scale agriculture in gardens and fields [5]. Studying the relationship between people and plants and the significance of plant use knowledge towards the wellbeing of the community is extremely important $[4,6]$.

Ethiopia is the home of amazing system of indigenous knowledge that supports people to survive under adverse environmental conditions, famine and poverty [7]. The country is also diverse in climatic conditions, topographic and edaphic variation that enable occurrence of a wide range of vegetation from tropical rain and cloud forests to the desert scrubs [8]. Awash National Park is found in arid and semi-arid environment which is faced many problems from drought, population and livestock pressures. Two ethnic peoples (Oromo and Afar) live surrounding the Park and frequently compete on utilization of plant resources, which posed many problems on plant resources in the park as well as in the surrounding area before documentation on the importance of useful plants. Most previous studies in the site have been focused on plant diversity, composition and structure $[9,10]$. Therefore, it is very needed to document the local knowledge of communities on useful plants for the conservation and management of plant species in and around Awash National Park.

\section{Materials and Methods}

\section{Description of the study area}

Awash National Park is located at $9^{\circ} 20^{\prime} \mathrm{N}$ and $40^{\circ} 20^{\prime} \mathrm{E}$. It is in the lowlands of Ethiopia at $215 \mathrm{Km}$ North-East of Addis Ababa, covering an area of $756 \mathrm{Km}^{2}$. The climatic condition of the park is arid and semi-arid, with an average annual rainfall of $620 \mathrm{~mm}$.

The park serves as home of Ethiopia's largest Beisa oryx population and is the second most important critical area, where some endangered, endemic and migratory bird species live. The presence of 


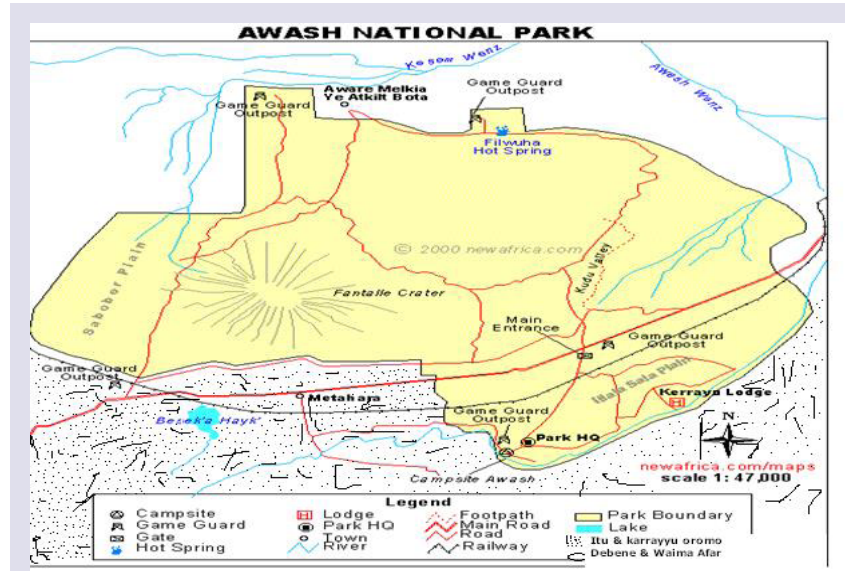

Figure 1: The Awash National Park, the surrounding Afar and Oromo tribes.

unique botanical features including Doum palm and riverine forests make the park attractive. The park is also characterized by unique landscape scenery and geological features including Fentale Crater, Ilala Sala plains and grasslands, Hot spring area and the gorge which represent an important income and food source for local communities. The Filwuha hot springs are important for curing illnesses such as malaria, the oldest educational museum and the lodges inside have diverse and unique ethnic/cultural features, including the Seats for Gada system and the Belaadas in Afar, an ideal place of a training site for ornithologists, primatologists and archaeologists and vital watering points for livestock, including Hakaki and the hot springs [11].

\section{Socioeconomic of the two ethnic peoples}

The park is surrounded by two regions; namely Afar (Awash Fantale district) and Oromia (Fantale district) regions (Figure 1). The Karrayyu and Ittu clans of Afan Oromo speakers found to the South and South West of the Park. The Karrayyu Oromo are pure pastoralists whereas the Ittu Oromo are agro-pastoralists. The Afar tribes are located at the North (Debene Clan) and East (Waima clan) of the park [12]. Pastoral agriculture is practiced mainly at an elevation below $1,500 \mathrm{~m}$ a.s.l. with annual rainfall of below $450 \mathrm{~mm}$.

In the arid zone, nomadic and semi nomadic pastoral livestock production depend on camels and goats as important components. In the semi-arid, semi-nomadic or semi-sedentary zone, livestock production is practiced. The major components of the livestock production are cattle and sheep, although camels and goats are found. Both water and range development is important element to improve livestock production here. Low moisture is the major production constraint particularly in the arid zone. In this zone, there is a high potential for irrigated agriculture, especially for production of fiber crops, sugar cane, oil seeds, horticultural and forage crops can be produced.

\section{Data collection and identification methods}

Ethnobotanical data were collected from four Kebeles in the surrounding areas of Awash National Park. The ethnobotanical data collection was based on semi structured interviews, field observation, preference and direct-matrix ranking [4,13]. A total of 60 informants
(42 male and 18 female) were involved in the interview. In which, 15 key informants were identified by following systematic method of informant selection [4,13] and other informants were selected randomly [13].

Preference ranking for five medicinal plants was analyzed to understand people perception on identification of efficacy plants. Direct matrix ranking for seven multiple uses of plants was analyzed to determine the main cause for overharvesting of the respective plants $[4,13]$. Identification of useful plant specimens collected from the study area was performed using taxonomic keys and Flora of Ethiopia and Eritrea [14-21] and deposited in Samara University.

\section{Data analysis}

Ethnobotanical data were entered into excel spreadsheet and ethnomedicinal uses and taxonomic groups were analyzed using descriptive statistics. The level of homogeneity between information provided by different informants was calculated using the Informants' Consensus Factor (ICF) [22]. It is calculated as:

$$
I C F=\frac{N u r-N t}{(N u r-1)}
$$

Where, Nur is the number of use reports from informants for a particular plant-usage category and $\mathrm{Nt}$ is the number of species that are used for that plant usage category for all informants. Values range between 0 and 1, where " 1 " indicates the highest level of informant consent. In this study, five use categories for all informants reported frequently were chosen and consensus factors were calculated.

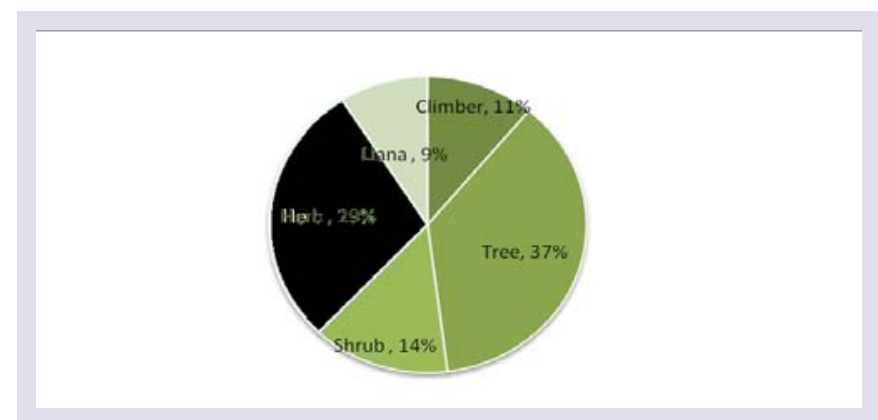

Figure 2: The proportion of growth habit of medicinal plants.

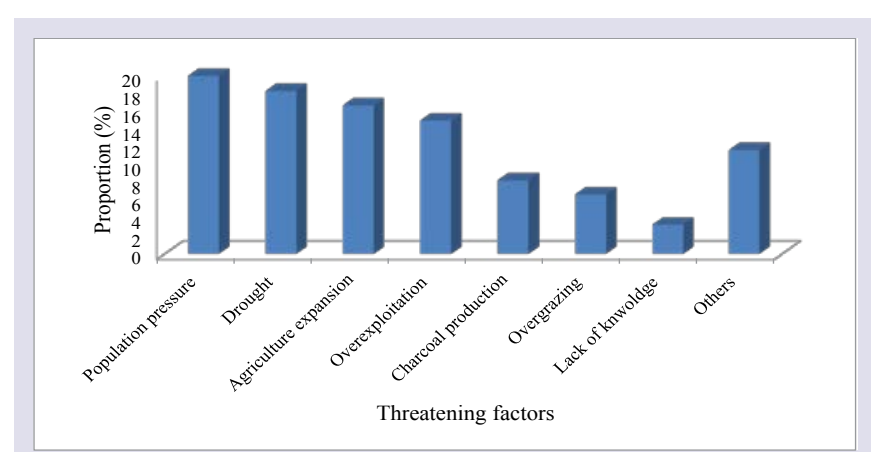

Figure 3: Threatening factors to useful plants. 


\section{Use value of useful plants}

Species importance was estimated by using use value analysis [23]. In the use value analysis, the plants were categorized into three classes, no use, minor use, and major use. The use value scores assigned to these classes were, $0,0.5$, and 1 respectively [23]. The plant use value was analyzed to evaluate the importance of each plant species to the ethnic people and calculated as the average use value of the species using the following formula:

$$
\text { Uvis }=\frac{\sum U i s}{n i s}
$$

Where, Uvis = the use value $(\mathrm{Uv})$ attributed to a particular species (s) by one informant $\mathrm{m}(\mathrm{i})$; $\Sigma \mathrm{Uis}=$ summation of all the uses mentioned in each event by the informant; nis = total number of events in which that informants give information on the species.

\section{Results and Discussions}

\section{Taxonomic diversity}

A total of 62 useful plant species belonging to 49 genera and 31 families were collected and identified from the study area. The family Fabaceae represented the highest number of species 11 species (18\%), followed by Malvaceae and Solanaceae each with 5 species (8\%), Acanthaceae with 4 species (6.4\%), Asclepiadaceae and Cucurbitaceae each with 3 species (4.8\%), Capparidaceae, Lamiaceae, Moraceae, Poaceae, Rhamnaceae and Tiliaceae each with two species. The growth form distribution showed that majority of the species were trees ( $35.5 \%, 22$ species) followed by shrubs ( $25.8 \%, 16$ species), herb (24\%, with 15 species). Others were liana and climbers. More woody species recorded in the sites were because of higher adaptation of these plant species in the harsh environment than that of herbaceous species.

\section{Major use categories and informant consensus factors}

The result of the study showed that five major use categories of plants were recorded. From major use categories, 35 medicinal species which were used to the treatment of human, cattle, goat, sheep and camel ailments; 22 wild edible species, 39 forage species, 17 cosmetics and beauty and 45 species used for construction, fuel and firewood (Table 1) were identified and documented on the base of their uses. The diversity of useful plants in the area was less compared with other regions [24-26]. This might be due to factors like over-exploitation and other environmental problems. The level of homogeneity between information provided by different informants was calculated using the Informants' Consensus Factor [22]. Five reported use categories were frequently chosen and consensus factors were calculated (Table 1).

Table 1: Major use categories and their informant consensus factor (ICF).

\begin{tabular}{|l|l|l|l|l|l|}
\hline Major Use Category & Families & Genera & Species & $\begin{array}{l}\text { Use } \\
\text { citation }\end{array}$ & ICF \\
\hline $\begin{array}{l}\text { Medicinal plants } \\
\text { Health and cosmetics }\end{array}$ & 20 & 30 & 35 & 92 & 0.63 \\
Wild edible plants & 12 & 15 & 17 & 33 & 0.50 \\
Forage species & 15 & 17 & 22 & 73 & 0.71 \\
$\begin{array}{l}\text { Construction, fuel and } \\
\text { charcoal }\end{array}$ & 21 & 33 & 39 & 125 & 0.69 \\
\hline
\end{tabular}

\section{Forage plants}

The Awash National Park is a national park that surrounded by pastoralists' people, who use a variety of habitats and plant species for their livestock feed. They utilize the surrounding area in a grazing mechanism. Thirty nine (62.9\%) useful plants were used for forage, being distributed in 21 families and 33 genera. More than half (61\%) of forage species belong to Poaceae, Fabaceae, Acanthaceae, Solanaceae, Tiliaceae, Capparidaceae, Cucurbitaceae, Malvaceae and Moraceae. The most important livestock feeds were documented, including trees 17 (43\%), shrubs 9 (23\%), herb 10 (26\%), climber 2 (5\%), liana $1(2.5 \%)$ species (Table 2 ). This was comparable with plant biodiversity of Borana Pastoralists [25] and higher in species number of forages with other regions [27]. This indicated that the knowledge of the people on the forage plants and their uses vary from lowland to highland. In the lowland area, pastoralists' life depends on livestock production that utilized more forage species than sedentary agropastoralists.

Some forage plants, such as Rostraria cristata, Solanum campylacanthum and Polypogon viridis were highly utilized plants for livestock feed. Rostraria cristata was perceived as the best grass that tended to increase milk production and it was also the most available grass type. The survey result from informants indicated that availability of pasture area has declined from time to time. The main reasons were increasing animal and human population, droughts, encroachment of pasture lands by invasive, especially Prosopis sp. high protection of national parks for wildlife protection and insecurity resulting from conflicts with other pastoral communities [28].

\section{Medicinal plants}

A total of 35 species (56.5\% of the useful plants) belonging to 20 families and 30 genera were identified as medicinal plants (Table 3 ). Roots and Leaves were most frequently used parts followed by stems and fruits. Of the total medicinal plants, 23 species (66\%) were used as human medicine, five species (15\%) as livestock medicine and the remaining seven species (20\%) for treating both human and livestock ailments. These medicinal values attributed medicinal plants to be significant use category in the study area as similar studies have shown with other pastoralist in Ethiopia [24-26]. Medicinal tree species were accounted to the highest proportion being representing with 13 species (37\%) followed by herbs (10 sp., $29 \%$ ), shrub (5 sp., $14 \%$ ), climbers (4 sp., 11\%) and lianas (3 sp., $9 \%$ ) (Figure 2).

The result agreed with other study on medicinal plants in Ethiopia [25]. As most of people living in the rural area particularly in pastoralists' had limited accessibility of modern medicine, traditional medicine might play highly important ways of ailment treatments. Such conditions had been forced pastoralists to depend on utilization of medicinal plants that might support to discover new products for modern medicine. However, availability of medicinal plants was declining in an alarming rate due to overexploitation and conflicts on the natural resource. In addition, uses of plant root parts for medicinal purpose suggested being another major problem in pastoralists as similar study has reported [29].

\section{Preference ranking}

Preference ranking of five medicinal plants that reported as 
Citation: Beche D, Gebeyehu G, Feyisa K. Indigenous Utilization and Management of Useful Plants in and around Awash National Park, Ethiopia. J Plant Biol Soil Health. 2016;3(1): 12.

ISSN: 2331-8996

Table 2: List of forage plants utilized by the pastoralists (Key: DGK means codes of plant specimen numbers).

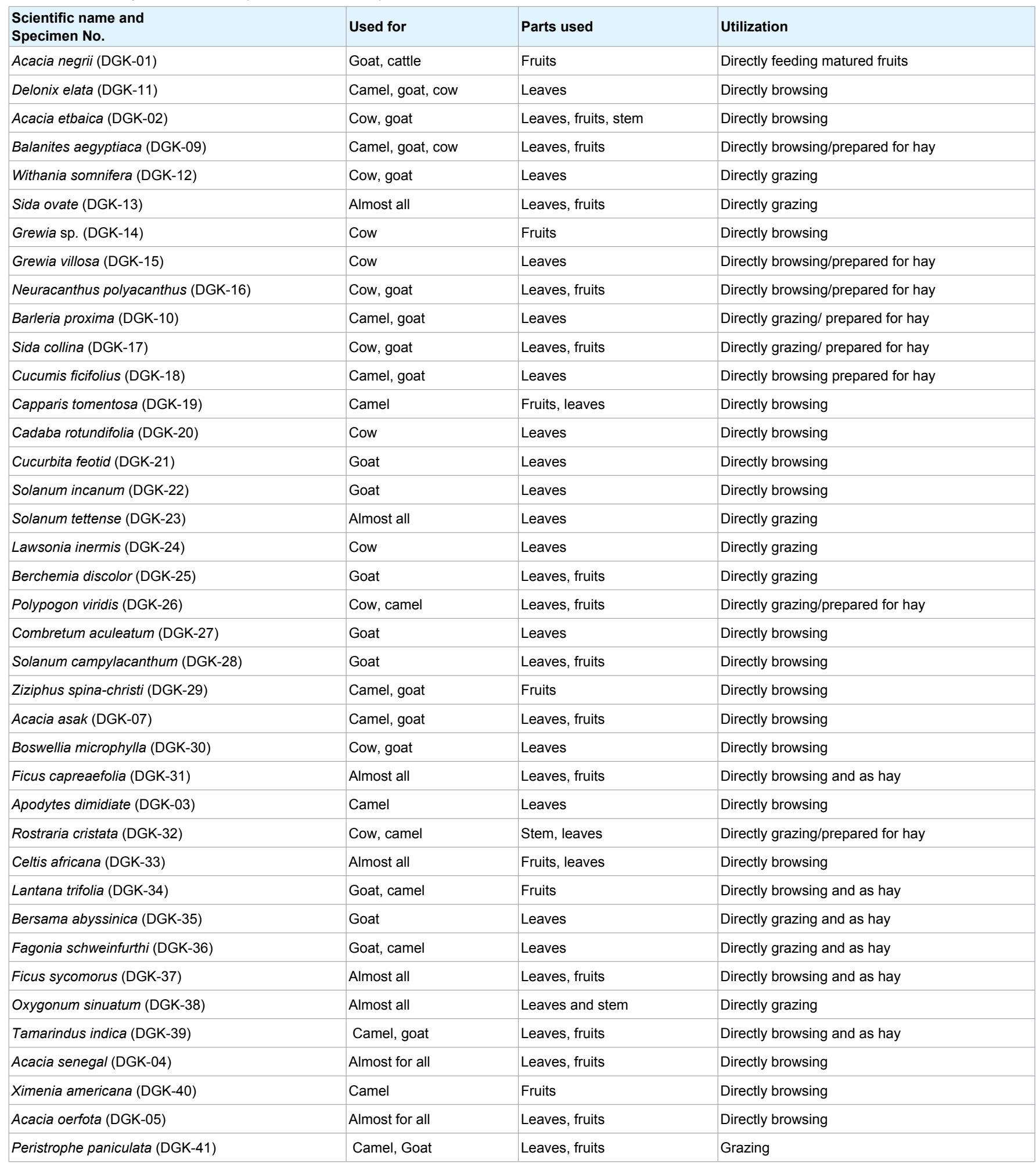

effective for treating different kind of wounds was conducted after selecting 15 key informants. The informants were asked to compare the given medicinal plants based on their efficacy, and to give the highest number ten for the medicinal plant which they thought the highest effective in treating wounds and the lowest number one for the least effective plant in treating wounds As shown in Table 4 below, Acacia negrii was scored the highest mark and ranked first indicating that it is suggested to be the most effective in treating wound followed by Acacia senegal. Ethnobotanical investigations done elsewhere in Ethiopia also reported that Acacia senegal has been used for different 
Citation: Beche D, Gebeyehu G, Feyisa K. Indigenous Utilization and Management of Useful Plants in and around Awash National Park, Ethiopia. J Plant Biol Soil Health. 2016;3(1): 12.

ISSN: $2331-8996$

Table 3: List of medicinal plants and their indigenous utilization.

\begin{tabular}{|c|c|c|c|c|c|c|c|}
\hline \multirow{5}{*}{$\begin{array}{l}\text { Scientific name } \\
\begin{array}{l}\text { Acacia negrii } \\
\text { (DGK-01) }\end{array}\end{array}$} & \multirow{2}{*}{$\begin{array}{l}\text { Used for } \\
\text { Calf }\end{array}$} & \multirow{2}{*}{$\begin{array}{l}\text { Ailments treated } \\
\text { Over milk lactation }\end{array}$} & \multirow{2}{*}{$\begin{array}{l}\text { Parts used } \\
\text { Root }\end{array}$} & \multicolumn{2}{|c|}{$\begin{array}{l}\text { Conditions for } \\
\text { usage }\end{array}$} & \multirow{2}{*}{$\begin{array}{l}\text { Route of } \\
\text { administration }\end{array}$} & \multirow{2}{*}{$\begin{array}{l}\text { Preparation, application and dosage } \\
\text { Drinking the calf by crushing the root }\end{array}$} \\
\hline & & & & & Dry & & \\
\hline & Camel & Over milk drinking & Root & Fresh & & Oral & $\begin{array}{l}\text { Drinking the child camel by crushing and } \\
\text { chewing the root }\end{array}$ \\
\hline & & Anti-inflammatory & Leaves & & Dry & Dermal & Dried, crushed leaves attached to wound part \\
\hline & Human & $\begin{array}{l}\text { Injuries by spine and } \\
\text { gun }\end{array}$ & Leaves & Fresh & & Dermal & $\begin{array}{l}\text { Leaves are squeezed with water and pasted } \\
\text { on the wound and tied with clothes to prevent } \\
\text { flow of blood and healing of the wound. }\end{array}$ \\
\hline \multirow{6}{*}{ Balanites aegyptiaca } & \multirow{3}{*}{ Human } & Snake bite & Root & Fresh & & Oral & $\begin{array}{l}\text { Fresh roots are crushed, squeezed with water } \\
\text { and one liter is drunk orally }\end{array}$ \\
\hline & & Madness & Root & Fresh & & Oral & $\begin{array}{l}\text { Roots are crushed and few squeezed is given } \\
\text { orally due to burning }\end{array}$ \\
\hline & & Typhus & Root & Fresh & & Oral & $\begin{array}{l}\text { Roots are crushed and boiled in water until } \\
\text { forms foam then three liters are given to } \\
\text { camels. }\end{array}$ \\
\hline & Goat & Eye problem & Root & Fresh & & Oral & $\begin{array}{l}\text { Roots are crushed, diluted in water and then } \\
\text { stirred to form foam so that three liters are } \\
\text { given }\end{array}$ \\
\hline & \multirow[t]{2}{*}{ Camel } & Anthrax & Fiber & & Dry & Oral & $\begin{array}{l}\text { The death of cattle by the case of anthrax, } \\
\text { its meat is boiled with fibers and washed } \\
\text { then eaten as a food. This prevents death of } \\
\text { humans. }\end{array}$ \\
\hline & & Eye problem & Root & Fresh & & Dermal & $\begin{array}{l}\text { Roots are crushed and one liter squeezed is } \\
\text { given orally }\end{array}$ \\
\hline $\begin{array}{l}\text { Zehneria anomala } \\
\text { (DGK-42) }\end{array}$ & Human & $\begin{array}{l}\text { Accidental tiredness } \\
\text { of children }\end{array}$ & Leaves & Fresh & & Oral & $\begin{array}{l}\text { Fresh leaves are squeezed with water and one } \\
\text { spoon is given orally. }\end{array}$ \\
\hline Grewia villosa & Human & Stomach ache & Fruits & & Dry & Oral & $\begin{array}{l}\text { Fruits are crushed and diluted in water and } \\
\text { given orally }\end{array}$ \\
\hline \multirow{3}{*}{ Delonixelata (DGK-43) } & \multirow{3}{*}{ Human } & Tonsillitis & Root & Fresh & & Oral & Chewing and swallowing only the chemical \\
\hline & & Tooth ache & Root & Fresh & & Oral & Used as tooth brush \\
\hline & & Snake bite & Root & Fresh & & Oral & Chewing of the roots \\
\hline $\begin{array}{l}\text { Azadirachta indica } \\
\text { (DGK-06) }\end{array}$ & Human & $\begin{array}{l}\text { Malaria } \\
\text { Dysentery }\end{array}$ & Leaves & Fresh & & Oral & $\begin{array}{l}\text { Fresh leaves are crushed and squeezed with } \\
\text { water and filter then one cup is given orally. }\end{array}$ \\
\hline $\begin{array}{l}\text { Acacia etbaica (DGK- } \\
02 \text { ) }\end{array}$ & Human & Wound (Dhitto) & Leaves & & Dry & Dermal & Tied on the wound \\
\hline Sida urens (DGK-44) & Cow & Injury & Root & Fresh & & Dermal & $\begin{array}{l}\text { Leaves are crushed and creamed on the } \\
\text { wound }\end{array}$ \\
\hline \multirow{2}{*}{$\begin{array}{l}\text { Parthenium } \\
\text { hysterophorus } \\
\text { (DGK-45) }\end{array}$} & Human/child & Diarrhea & Stem & Fresh & & Oral & $\begin{array}{l}\text { Crushing the whole part and one cup is given } \\
\text { orally }\end{array}$ \\
\hline & $\begin{array}{l}\text { Human } \\
\text { (adult) }\end{array}$ & Stoma ache & Root & Fresh & & Oral & $\begin{array}{l}\text { Root is chewed directly } \\
\text { Roots are crushed and soaked in water and } \\
\text { one can is given but have high bitter taste }\end{array}$ \\
\hline $\begin{array}{l}\text { Senna petersiana } \\
\text { (DGK-47) }\end{array}$ & Human & $\begin{array}{l}\text { Wound } \\
\text { Snake bite }\end{array}$ & Root & Fresh & & Oral & Crushed and filtered, then drinking \\
\hline \multirow{2}{*}{$\begin{array}{l}\text { Acacia senegal } \\
(\text { DGK-04) }\end{array}$} & \multirow{2}{*}{ Human } & Prevent bleeding & Fibers & Fresh & & Dermal & Fibers are tied to injured parts \\
\hline & & Blotting & Resin & Fresh & & Oral & Resin is directly swallowed \\
\hline
\end{tabular}


Citation: Beche D, Gebeyehu G, Feyisa K. Indigenous Utilization and Management of Useful Plants in and around Awash National Park, Ethiopia. J Plant Biol Soil Health. 2016;3(1): 12.

ISSN: 2331-8996

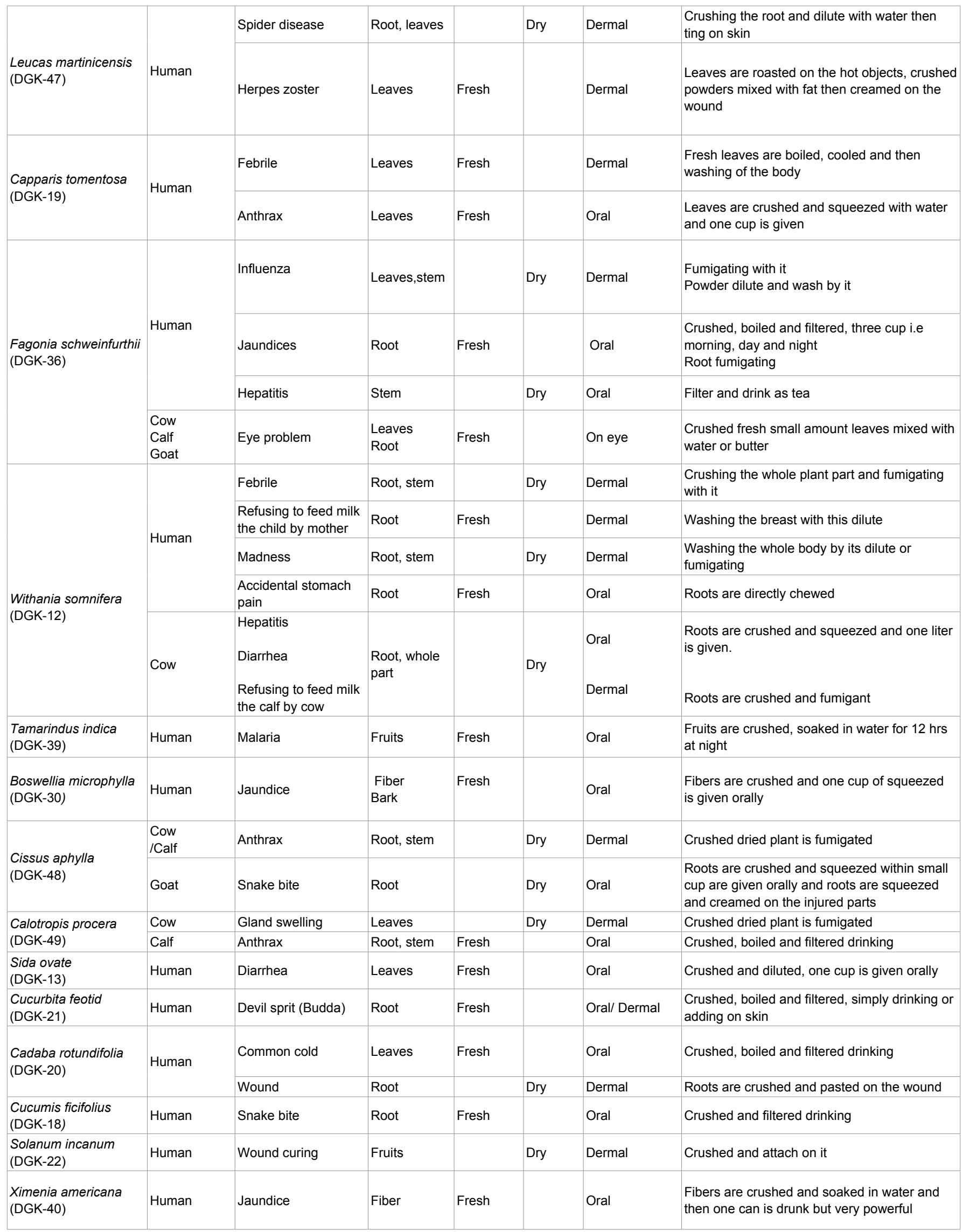


Citation: Beche D, Gebeyehu G, Feyisa K. Indigenous Utilization and Management of Useful Plants in and around Awash National Park, Ethiopia. J Plant Biol Soil Health. 2016;3(1): 12.

ISSN: 2331-8996

\begin{tabular}{|c|c|c|c|c|c|c|c|}
\hline \multirow{2}{*}{$\begin{array}{l}\text { Solanum } \\
\text { campylacanthum } \\
\text { (DGK-28) }\end{array}$} & Human & Abnormal activities & Stem & Fresh & & Dermal & Crushed and added to fire then fumigated \\
\hline & Camel & Cough & Fruits & & Dry & Oral & Drinking the child camel by adding with salt \\
\hline \multirow{3}{*}{$\begin{array}{l}\text { Prunus africana (DGK- } \\
56)\end{array}$} & \multirow[b]{2}{*}{ Human } & Gonorrhea & Root & Fresh & & Oral & $\begin{array}{l}\text { Roots are crushed, diluted in water and one } \\
\text { bottle is drunk }\end{array}$ \\
\hline & & Impotency & Root & Fresh & & Oral & $\begin{array}{l}\text { Fresh roots are crushed and soaked in water } \\
\text { and then one cup is drunk. }\end{array}$ \\
\hline & Camel & $\begin{array}{l}\text { Jinni/devil sprit/ } \\
\text { abnormal activities }\end{array}$ & Stem & & Dry & Dermal & Crushed and added to fire then fumigated \\
\hline $\begin{array}{l}\text { Prosopis juliflora } \\
\text { (DGK-49) }\end{array}$ & Human & Dysentery & Root & Fresh & & Oral & $\begin{array}{l}\text { Roots are crushed and soaked in water and } \\
\text { then filter and drink one cup of dilution. }\end{array}$ \\
\hline $\begin{array}{l}\text { Oxygonum sinuatum } \\
\text { (DGK-38) }\end{array}$ & Sheep & Swelling of neck & Leaves & & Dry & Oral & Crushed, boiled drinking them \\
\hline \multirow{4}{*}{$\begin{array}{l}\text { Ziziphus } \\
\text { spina-christi } \\
\text { (DGK-29) }\end{array}$} & \multirow{4}{*}{ Human } & Chest & Fruits & Fresh & & Oral & Eating the fresh fruit \\
\hline & & \multirow[t]{2}{*}{ Bone fracture } & $\begin{array}{l}\text { Leaves and } \\
\text { fibers }\end{array}$ & & Dry & Dermal & $\begin{array}{l}\text { Dried leaves and fibers are crushed together } \\
\text { and tied on the injured parts }\end{array}$ \\
\hline & & & Fruits & Fresh & & Oral & Eating the fresh fruit \\
\hline & & Corpse from decaying & Leaves & Fresh & & Dermal & $\begin{array}{l}\text { Leaves are crushed and diluted in water then } \\
\text { used for washing of corpse }\end{array}$ \\
\hline $\begin{array}{l}\text { Tacazzea conferta } \\
\text { (DGK-50) }\end{array}$ & Goat & Breast swelling & Root, stem & & Dry & Oral & Crushing, diluting then drinking \\
\hline $\begin{array}{l}\text { Jasminium } \\
\text { grandiflorum (DGK-5) }\end{array}$ & Human & $\begin{array}{l}\text { Leg wound due to } \\
\text { snake bite }\end{array}$ & Root & Fresh & & Oral & $\begin{array}{l}\text { Crushed, boiled and filtered, then taken with } \\
\text { water }\end{array}$ \\
\hline $\begin{array}{l}\text { Solanum tettense } \\
\text { (DGK-23) }\end{array}$ & Human & Constipation & Root & & Dry & Oral & $\begin{array}{l}\text { Roots are crushed, diluted in water and one } \\
\text { cup is given orally }\end{array}$ \\
\hline $\begin{array}{l}\text { Crossandra mucronata } \\
\text { (DGK-52) }\end{array}$ & Human & Flies prevention & Leaves & & Dry & Dermal & Fumigant to prevent flies \\
\hline
\end{tabular}

Table 4: Preference ranking of five medicinal plants used to cure wounds.

\begin{tabular}{|c|c|c|c|c|c|c|c|c|c|c|c|c|c|c|c|c|c|}
\hline \multirow[b]{2}{*}{ Medicinal plants } & \multicolumn{15}{|c|}{ Key Respondents } & \multirow{2}{*}{$\begin{array}{l}\text { Total } \\
\text { score }\end{array}$} & \multirow{2}{*}{ Rank } \\
\hline & $\mathrm{R}_{1}$ & $\mathrm{R}_{2}$ & $\mathrm{R}_{3}$ & $\mathrm{R}_{4}$ & $\mathrm{R}_{5}$ & $\mathrm{R}_{6}$ & $\mathrm{R}_{7}$ & $\mathrm{R}_{8}$ & $\mathrm{R}_{9}$ & $\mathrm{R}_{10}$ & $\mathrm{R}_{11}$ & $\mathrm{R}_{12}$ & $\mathrm{R}_{13}$ & $\mathrm{R}_{14}$ & $\mathrm{R}_{15}$ & & \\
\hline Cadaba rotundifolia & 7 & 10 & 6 & 4 & 8 & 3 & 10 & 7 & 8 & 7 & 5 & 6 & 7 & 5 & 6 & 99 & $3^{\text {rd }}$ \\
\hline Ziziphus spina-christi & 3 & 7 & 9 & 5 & 5 & 5 & 4 & 6 & 5 & 4 & 8 & 10 & 6 & 7 & 8 & 92 & $5^{\text {th }}$ \\
\hline Acacia senegal & 8 & 5 & 10 & 6 & 6 & 4 & 3 & 5 & 4 & 9 & 6 & 8 & 9 & 10 & 7 & 100 & $2^{\text {nd }}$ \\
\hline Senna petersiana & 4 & 8 & 5 & 7 & 10 & 6 & 6 & 3 & 6 & 5 & 9 & 3 & 4 & 8 & 10 & 94 & $4^{\text {th }}$ \\
\hline
\end{tabular}

( $\mathrm{R}_{1-15}$ are respondents/informants; from R1-8 for Oromo/ R9-15 for Afar pastoralists;

the values 1 = least used to cure wounds, $10=$ highly used to cure wound

ethnomedicinal purpose [25]. Further pharmacological test of the species against wound curing might reveal promising results.

\section{Wild edible plants}

The result of the study revealed that 22 wild edible species (35.5\%) belonging to 17 genera and 15 families were documented in the site (Table 5). This indicated that the study area has potential source of wild edible species. Fabaceae had the highest proportion of edibles with seven species, followed by Rhamnaceae and Tiliaceae accounted two species respectively. Most of the identified species were reported to be edible elsewhere in Ethiopia and in other countries of Africa. For example, of the species recorded in this study, eight species were documented elsewhere in Ethiopian lowlands [25]. Most plant parts were eaten directly in fresh forms. Out of total edible plants, nine species were commonly used in both ethnic groups. The Oromo (Ittu and Kereyyu) tribes affirmed that $10(45 \%)$, and Afar (Wa'ema and Debene) 3 (14\%) of the 22 edibles species in the study area. Utility of these species over wider areas among different communities 
Citation: Beche D, Gebeyehu G, Feyisa K. Indigenous Utilization and Management of Useful Plants in and around Awash National Park, Ethiopia. J Plant Biol Soil Health. 2016;3(1): 12.

\section{ISSN: 2331-8996}

Table 5: List of wild edible plant species with their used parts and way of preparations.

\begin{tabular}{|c|c|c|c|}
\hline Local name & Scientific name & Parts used & Preparation and consumption \\
\hline Ajoo & Acacia etbaica & Latex & Fresh resin is swallowed \\
\hline Adachaa & Acacia negrii & Latex & Fresh resin is swallowed \\
\hline Wangayoo & Acacia oerfota & Fruits & Unripe fruits are eaten \\
\hline Addado & Acacia senegal & Latex & Fresh resin is swallowed \\
\hline Wacho & Acacia seyal & Latex & Fresh resin is swallowed \\
\hline Manqeroo & Apodytes dimidiata & Fruits & Ripen fruits are eaten \\
\hline Bedeno & Balanites aegyptiaca & Fruits & Unripe fruits are eaten \\
\hline Jejjeba & Berchemia discolor & Fruits & Ripen fruits are eaten \\
\hline Leeddi & Boswellia microphylla & Fruits & Ripen fruits are directly eaten \\
\hline Metekoma & Celtis africana & Fruits & Ripen fruits are eaten directly \\
\hline Hiwak & Crossandra mucronata & Fruits & Unripe fruits are eaten \\
\hline Dheekkaa & Grewia sp. & Fruits & Both ripen and unripe fruits are eaten \\
\hline Dogomdii & Grewia villosa & Fruits & Unripe fruits are eaten \\
\hline Midhandurbaa & Lantana trifolia & Fruits & Both ripen and unripe fruits are eaten \\
\hline Adde & Olinia rochetiana (DGK-53) & Fruits & Unripe fruits are eaten \\
\hline Domaa & Phoenix reclinata (DGK-54) & Fruits & Both ripen and unripe fruits are eaten \\
\hline Killaa & Polypogon viridis (DGK-55) & Fruits & Unripe fruits are eaten \\
\hline Garuwyto & Sida collina & Fruits & Unripe fruits are eaten \\
\hline Roka & Tamarindu sindica & Fruits & Both ripen and unripe fruits are eaten \\
\hline Huddaa & Ximenia americana & Fruits & Both ripen and unripe fruits are eaten \\
\hline
\end{tabular}

Table 6: List of plant species used for cosmetics and beauty.

\begin{tabular}{|c|c|c|}
\hline Scientific name & Parts used & Preparation and application \\
\hline $\begin{array}{l}\text { Cyperus } \\
\text { Rigidifolius (DGK-57) }\end{array}$ & Bulb & The bulbs are dried and fumigated to house for good smell \\
\hline Capparis tomentosa & Stem & Dried and fumigated to whole body specially for female \\
\hline Senna truncate (DGK-58) & Branches & Directly brushing of teeth \\
\hline Balanites aegyptiaca & Bark & Fumigating it to the whole bed \\
\hline Delonix elata & Branches & As Body lotion \\
\hline Boswellia microphylla & Stem, Branches & Fumigant to have good smell of the houses or women \\
\hline Tamarindus indica & Fruits, leaves & Dried, crushed, soaked in water to be used as lotion \\
\hline Lawsonia inermis & Leaves & To color the hand \\
\hline Sida collina & Bark & Hair beauty for freezing like shampoo, especially for male \\
\hline Ziziphus spina-christi & Leaves & Leaves are crushed and creamed on the hairs or body to make smooth and shiny \\
\hline Berchemia discolor & Stem & For young female as stem bath \\
\hline Solanum campylacanthum & Stem & Sliced stem by fumigating like as steam bath \\
\hline Solanum incanum & Fruits & Crushed fruit to mix it with water to wash their legs \\
\hline Grewia villosa & Fibers, Bark & Crushed fibers soaked in water and form foam so that wash of hair with this. \\
\hline Grewia sp. & Bark & Fibers are crushed, soaked in the water and form foam so that wash of hair \\
\hline Fagonia schweinfurthii & Whole plant & Steam bath \\
\hline
\end{tabular}


Citation: Beche D, Gebeyehu G, Feyisa K. Indigenous Utilization and Management of Useful Plants in and around Awash National Park, Ethiopia. J Plant Biol Soil Health. 2016;3(1): 12.

\section{ISSN: 2331-8996}

Table 7: Plant uses for construction, charcoal and firewood and others.

\begin{tabular}{|c|c|}
\hline Scientific name & Utilization \\
\hline Acacia negrii & Production material of chair, spoon, traditional dish \\
\hline Olinia rochetiana & Traditional house construction \\
\hline Acacia etbaica & House construction \\
\hline Cryptostegia grandfloria (DGK-59) & House construction \\
\hline Leucas martinicensis (DGK-60) & Roof of traditional house \\
\hline Balanites aegyptiaca & The roof material of traditional house construction \\
\hline Datura stramonium (DGK-61) & Protection from termite \\
\hline Senna petersiana & Fence \\
\hline Grewia sp. & Best stick for camel keepers \\
\hline Grewia villosa & For material of farm production \\
\hline Barleria proxima & Fence of goat and camel room \\
\hline Sida tenuicarpa & House construction \\
\hline Sida rhombifolia & Door of traditional house \\
\hline Capparis tomentosa & Fence \\
\hline Cadaba rotundifolia & Sticks for men \\
\hline Lawsonia inermis & Washing died people with it \\
\hline Ximenia americana & $\begin{array}{l}\text { Thick stick for adults, Cultural pray } \\
\text { Wood of diggers, House construction }\end{array}$ \\
\hline Berchemia discolor & Headboard, House construction especially roof \\
\hline Senna truncate & Farming material \\
\hline Crossandra mucronata & House construction \\
\hline Combretum aculeatum & Bed sheet \\
\hline Polypogon viridis & Bed sheet, roof \\
\hline Ziziphus spina-christi & $\begin{array}{l}\text { Religious purpose/pray especially for Afar people } \\
\text { Raw material of chair, spoon, cultural dish }\end{array}$ \\
\hline Acacia asak & For cultural gatherings \\
\hline Boswellia microphylla & For stick of women during praying and wedding ceremony \\
\hline Ficus capreaefolia & As stick, farming material production \\
\hline Apodytes dimidiata & Mainly charcoal production \\
\hline Rostraria cristata & $\begin{array}{l}\text { House roof; Agricultural equipments; Charcoal production } \\
\text { Cosmetics (leaves) as hinna for hair; Honey production }\end{array}$ \\
\hline Phoenix reclinata & Leaves as bed sheet, as sign of peace during ceremonies \\
\hline Prunus africana & Stick during cultural ceremonies \\
\hline Lantana trifolia & As ornamental for young women \\
\hline Bersama abyssinica & As fence or Door of cultural house \\
\hline Celtis africana & Highly used for traditional house construction and fencing \\
\hline Azadirachta indica & Wind break, shadow \\
\hline Ficus sycomorus & House making \\
\hline Prosopis juliflora & Agricultural equipments, fuel-charcoal \\
\hline Sida tenuicarpa & Used during harvesting cereals \\
\hline Cyperus rigidifolius & As bed sheet, and during cultural day in house \\
\hline Tacazzea conferta & Ornamental, fence of irrigation land \\
\hline Jasminium grandiflorum & House connector \\
\hline Peristrophe paniculata & Door for animal fence \\
\hline Ipomoea cairica (DGK-62) & Ting of different part of house \\
\hline Acacia senegal & Traditional house construction \\
\hline Acacia seyal & Fence \\
\hline Acacia oerfota & Traditional house construction and fuel wood \\
\hline
\end{tabular}


Citation: Beche D, Gebeyehu G, Feyisa K. Indigenous Utilization and Management of Useful Plants in and around Awash National Park, Ethiopia. J Plant Biol Soil Health. 2016;3(1): 12.

ISSN: $2331-8996$

Table 8: Direct matrix ranking of multipurpose uses of plants.

\begin{tabular}{|c|c|c|c|c|c|c|c|}
\hline \multirow{3}{*}{$\begin{array}{l}\text { List of plant species } \\
\text { Boswellia microphylla }\end{array}$} & \multicolumn{5}{|c|}{ Use categories } & \multirow{2}{*}{\multicolumn{2}{|c|}{ Total Rank }} \\
\hline & \multirow{2}{*}{\begin{tabular}{|l|} 
Food \\
1 \\
\end{tabular}} & \multirow{2}{*}{\begin{tabular}{|l} 
Medicine \\
5
\end{tabular}} & \multirow{2}{*}{$\begin{array}{l}\text { Forage } \\
2\end{array}$} & \multirow{2}{*}{$\begin{array}{l}\text { Cosmetics } \\
4\end{array}$} & \multirow{2}{*}{$\begin{array}{l}\text { Miscellaneous Uses } \\
5\end{array}$} & & \\
\hline & & & & & & 17 & $2^{\text {nd }}$ \\
\hline Ziziphus spina-christi & 5 & 4 & 3 & 2 & 4 & 18 & $1^{\text {st }}$ \\
\hline Acacia negrii & 2 & 3 & 4 & 1 & 3 & 13 & $6^{\text {th }}$ \\
\hline Balanites aegyptiaca & 3 & 4 & 3 & 2 & 4 & 16 & $3^{\text {rd }}$ \\
\hline Ximenia americana & 5 & 1 & 3 & 2 & 1 & 12 & $7^{\text {th }}$ \\
\hline Ficussycomorus & 4 & 1 & 4 & 1 & 5 & 15 & $4^{\text {th }}$ \\
\hline
\end{tabular}

( ${ }^{*} 1-5$ stands for average value given by informants, 1 means less use and $5=$ high use).

Table 9: Use value of frequently reported species of major categories.

\begin{tabular}{|l|l|l|l|l|}
\hline Species & Medicinal & Cosmetics & Forage & Wild edible \\
\hline Lawsonia inermis & & $39(0.6)$ & & \\
\hline Grewia villosa & $22(0.61)$ & $45(0.63)$ & $57(0.3)$ & \\
\hline Rostraria cristata & & & & \\
\hline Fagonia schweinfurthii & $34(0.03)$ & $26(0.36)$ & $28(0.4)$ & \\
\hline Senna petersiana & & & & $25(0.15)$ \\
\hline Solanum incanum & & & & $25(0.15)$ \\
\hline Ziziphus spina-christi & & & & \\
\hline Balanites aegyptiaca & & & & \\
\hline Acacia negrii & & & \\
\hline Acacia oerfota & & & \\
\hline
\end{tabular}

indicated the existence of common knowledge across a range of subsistence groups of different culture and geographic areas. Analysis of the results indicated that majority of the recorded edible species were consumed in fresh without ripening or processing (Table 5).

The informants asserted that edible fruit bearing species such as Ziziphus spina-christi and Ximenia americana were highly prized by individuals in all age groups. The reasons for appreciation of one species over the other, assumed to be easiness to eat, nutritional value and taste during consumption. In addition to food value, the identified species were marketable and provided the opportunity to supplement household income. This was observed in the study areas where various wild edible plants were sold at local market like fruits of Ziziphus spina-christi. The utilization of these species might gradually lead to the fading away of indigenous knowledge associated with the species and thus poses danger on poorer people who have relied on these cheap and relatively easily accessible food plants. Hence, many efforts need to promote the uses of these wild edibles through genetic and nutritional studies.

\section{Health, cosmetics and beauty}

The investigated 17 plant species have been commonly used for beauty and health purposes. Out of these, 13 species (62\%) accounted to woody plants including trees, liana and shrubs (Table 6). Plants, which were used as laundry and cleansing, fumigation, fragrance and aromatic characters of the area, were documented. For example, the bulbs of Cyperus rigidifolius were collected from underground, pounded, and mixed with butter to make a local perfume to take care of their hairs (Table 6).
Traditional fumigation and perfuming was a way by which female pastoralists use the smoke of some good-smelling aromatic species for cleaning their bodies and clothes. This traditional fumigation has advantages to clean bodies and make good smell which may be equivalent to modern perfumes. The most common species used for fumigations/cleansing include Cyperus rigidifolius, Boswellia microphylla and Solanum campylacanthum. Some species of plants in the area were used as hand lotion or coloring (e.g. Lawsonia inermis), body lotion (e.g. Delonix elata), steam bath (Fagonia schweinfurthii) that suggested to directly cleaning their skin in addition to perfuming. The most common type of cosmetics in the area were those plant species used for hair beauty and cleansing, such as Sida collina, Ziziphus spina-christi and Grewia villosa (Table 6), which were mostly prepared from fibers by crushing and soaking in water and using the foam to wash hair. These kinds of activities with similar species were reported from elsewhere $[25,26,30]$.

\section{Plant uses for construction, fuel and charcoal}

Different types of plant species have multiple values for uses of fuel, construction and charcoal production. Forty-five species belonging to 26 families, and 34 genera were recognized from the area (Table 7). Out of these, woody plants (tree, shrub, and liana) comprised 37 species (82\%), indicating that the woody plants were utilized more for different purposes than herbaceous plants in these categories. This showed that the Afar and Oromo ethnic people still depend on plant materials for house construction and other purpose. Furthermore, pastoralists depend on woods to make utensils for food preparation, containers (e.g. for farming material), and others (Table $8)$. 


\section{Use value of useful plants}

The use value was analyzed to evaluate the importance of each plant species to the ethnic people and calculated as the average use value of the species (Table 9). Such plants were intensively utilized by the pastoralists, and thus species availability might tend to decrease and finally lead to local extinction. If these excessive or unsustainable harvesting practices continue, plant species may be put at risk. For example, Boswellia microphylla, one of the most highly affected plants for different uses, is now restricted to the top of mountains in distribution.

As indicate above in Table 9, the frequently reported useful plants were analyzed for their informant's consensus factor from each category. In this study, Rostraria cristata was cited by $91.9 \%$ of the informants for forage followed by Grewia villosa (72.5\%) and Lawsonia inermis (62.9\%) usage for different cosmetics in the society. From different ethnobotanical categories different levels of cultural consensus were recognized. Use value was the highest in the category of cosmetics for species Grewia villosa (0.63) and followed by Lawsonia inermis (0.6). This analysis indicated that people highly depend on certain number of species for major uses than other species, and some species of those with higher use value were well known within the ethnic groups. Therefore, further study on the chemical content and their management should focus on species commonly used in the ethnic groups.

\section{Threatening factors of useful plants}

The respondents from both ethnic groups indicated that different factors played to threaten useful plants in their area (Figure 3) The result of the study showed that population pressure $(20 \%)$, drought (18.3\%) and agricultural expansion (16.7\%) were the major threatening factors to useful plants. Threatening factors of useful plants were recognized as environmental condition such as drought and anthropogenic factors. Anthropogenic factors played the dominant role in surviving of plant species in the site. Human demands for sources of food, medicine, shelter, cosmetics, construction, charcoal production and forage for livestock resulted in overexploitation and overgrazing of plants. The majority of plants used for livestock feed revealed that overgrazing played dominant factor in the study areas.

The results of the study showed that multiple utilizations of plants were recorded as the threatening factors similar to other previous studies in Ethiopia [31,32]. Therefore, most of the plant species in the areas have been facing lack of priorities for conservation especially the useful plants (medicinal, edible, forage plants). However, some farmers have started management of very few plants such as Ziziphus spina-christi and Balanites aegyptiaca in their farmlands. This showed that such management and acquisition of economic benefits from species might promote local peoples' interest in conservation and maintenance of such local important plants.Such experiences should be exchanged with other local people to motivate conservation and management habit in the area.

\section{Conclusions and Recommendations}

The result of the study revealed that 62 useful plant species were found having vital roles in subsistence wellbeing to the society which was reflected by presence of five major use categories. The key products harvested from useful plants were edible parts, traditional medicine, forage, cosmetics and other miscellaneous benefits. The majority of products were found from woody species which were dominant useful plant components in the study area. The survival status of some useful species particularly in herbaceous plant species has declined.

The major threatening factors for useful plants were recognized from environmental condition such as drought and anthropogenic activities. Anthropogenic activities took the dominant role and exerted many pressures on plant resources. Multiple uses of plants for charcoal production; forage uses and construction purpose made useful plants to be at risk conditions. These demand an urgent attention to conserve such vital resources. The rising awareness on utilization of plants in sustainable manner and minimization of conflicts in both ethnic groups might be promising solutions to reduce threatening factors. Therefore, conservation and management of useful plants should be regulated in collaboration and participation of local communities, districts, park reserves and federal administration.

A rich heritage of indigenous plant use and knowledge was recognized in almost similar manner in both ethnic groups. However, awareness rising for highly knowledgeable elders needed to avoid erosion of the indigenous knowledge and to ensure sustainable and preservation of indigenous knowledge for future generation. Supporting the present investigation, pharmaceutical and nutritional value of plants should be further evaluated to optimize their use in the future. It is recommended that further studies in other ethnobotanical plant use categories should be conducted to capture the entire plant diversity that needs conservation priorities.

\section{References}

1. Alcorn BJ (1984) Huastec mayan ethnobotany. University of Texas Press, Austin, USA.

2. Ali H, Qaiser M (2009) The ethnobotany of chitral valley, Pakistan with particular reference to medicinal plants. Pak J Bot 41: 2009-2041.

3. Awas T, Demissew S, Bekele T (1997) Ethnobotanical study of non-cultivated plants in Gambella Region, Southwestern Ethiopia. In: Fukui K, Kurimito E, Shagaeta S (Eds). 13th, International conference on Ethiopian studies; Ethiopia in broader perspective. Kyoto, Japan 3: 759-774.

4. Martin GJ (1995) Ethnobotany: a methods manual. Chapman and Hall, London, UK.

5. Asfaw Z, Nigatu A (1995) Homegardens in Ethiopia: characteristics and plant diversity. Sinet: Ethiop J Sci 18: 235-266.

6. Cotton CM (1996) Ethnobotany: principles and applications. John Wiley \& Sons, UK.

7. Fenta T (2006) Harnessing local and outsider's knowledge: Experiences of multi-stakeholder partnership to promote farmer innovation in Ethiopia. Prolinnova working paper 12

8. Teketay D, Lemenih M, Bekele T, Yemshaw $Y$, Feleke S, et al. (2010) Forest resources and challenges of sustainable forest management and conservation in Ethiopia. In: Bongers F, Tennigkeit T (Eds). Degraded forests in Eastern Africa: management and restoration. Earthscan, London, UK, pp.19-63.

9. Mekonnen M, Gebrehiwot K, Birhane E, Tewoldeberhan S (2009) Regeneration, density and diversity of woody vegetation in Awash National Park, Ethiopia. J Drylands 2: 101-109.

10. Yohannes T, Awas T, Demissew S (2013) Woody plant species diversity 
Citation: Beche D, Gebeyehu G, Feyisa K. Indigenous Utilization and Management of Useful Plants in and around Awash National Park, Ethiopia. J Plant Biol Soil Health. 2016;3(1): 12.

analysis in Awash National Park, Ethiopia. J Biodiversity Manage Forestry 2: $1-7$.

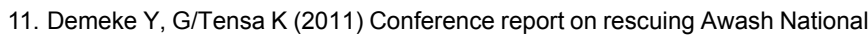
Park (Mat Pines, Ed). AdamaRas Hotel, Adama/Nazreth.

12. Mohamed MA (1988) Resource deprivation and socio-economic changes among the pastoral households: the case of Karayu and Ittu pastoralists in the middle Awash valley of Ethiopia. Master Thesis, Agricultural University of Norway.

13. Alexiades MN, Sheldon JW (1996) Selected guideline for ethnobotanical research: a field manual. New York Botanical Garden, New York.

14. Edwards S, Hedberg I (1997) Flora of Ethiopia and eritrea. Hydrocharitaceae to Arecaceae, vol 6. National Herbarium, Biology Department of Science Faculty, Addis Ababa University, Ethiopia, Uppsala, Sweden.

15. Edwards S, Tadesse M, Hedberg I (1995) Flora of Ethiopia and Eritrea. vo 2, part 2. Canellaceae to Euphorbiaceae. The National Herbarium, Addis Ababa, Ethiopia, Department of Systematic Botany, Uppsala, Sweden.

16. Edwards S, Tadesse M, Demissew S, Hedberg I (2000) Flora of Ethiopia and Eritrea. vol 2, part 1. Magnoliaceae to Flacourtiaceae. The National Herbarium, Addis Ababa, Ethiopia, Department of Systematic Botany, Uppsala, Sweden.

17. Hedberg I, Hedberg O, Egziabher TB, Edwards S, Uppsala universite Institutionen för systematisk botanik (1989) Flora of Ethiopia and eritrea. vol 3, Pittosporaceae to Araliaceae. National Herbarium, Addis Ababa, Ethiopia, Department of Systematic Botany, Uppsala, Sweden.

18. Hedberg I, Edwards S (1995) Flora of Ethiopia and eritrea. vol 7. Poaceae. The National Herbarium, Addis Ababa, Ethiopia, Department of Systematic Botany, Uppsala, Sweden.

19. Hedberg I, Edwards S, Nemomissa S (2003) Flora of Ethiopia and Eritrea. vol 4, part 1. Apiaceae to Dipsacaceae. The National Herbarium, Addis Ababa, Ethiopia, Department of Systematic Botany, Uppsala, Sweden.

20. Hedberg I, Friis I, Edwards S (2004) Flora of Ethiopia and Eritrea, vol 4, part 2. Asteraceae. The National Herbarium, Addis Ababa, Ethiopia, Department of Systematic Botany, Uppsala, Sweden.

21. Hedberg I, Kelbessa E, Edwards S, Demissew S, Persson E (2006) Flora of
Ethiopia and Eritrea vol 5, Gentianaceae to Cyclocheilaceae. The National Herbarium, Addis Ababa, Ethiopia, Department of Systematic Botany, Uppsala, Sweden.

22. Trotter RT, Logan MH (1986) Informant consensus: a new approach for identifying potentially effective medicinal plants. In: Etkin NL (Ed). Plants in indigenous medicine and diet: biobehavioral approaches. Redgrave Publishing Company, Bedfort Hills, New York, pp. 91-112.

23. Phillips O (1996) Some quantitative methods for analyzing ethnobotanical knowledge. In: Alexiades MN (Ed). Selected guidelines for ethnobotanical research: a field manual. New York Botanical Garden, New York, pp. 171197.

24. Seifu T, Asres K, Gebre-Mariam T (2004) Ethnobotanical and ethnopharmaceutical studies on medicinal plants of Chifra District, Afar Region, North Eastern Ethiopia. Ethiop Pharm J 24: 41-58.

25. Gemedo-Dalle T, Maass BL, Isselstein J (2005) Plant biodiversity and ethnobotany of Borana pastoralists in southern Oromia, Ethiopia. Economic Botany 59: 43-65

26. Lulekal E, Kelbessa E, Bekele T, Yineger H (2008) An ethnobotanical study of medicinal plants in Mana Angetu District, Southeastern Ethiopia. J Ethnobiol Ethnomed 4: 1-10.

27. Yineger $H$, Yewhalaw D, Teketay D (2008) Ethnomedicinal plant knowledge and practice of the Oromo ethnic group in southwestern Ethiopia. J Ethnobiol Ethnomed 4: 11

28. Philpott J, Abera A, Hadgu K (2005) Livelihoods/Emergency assessment in Afar Region. Oxfam International.

29. Piguet $F$ (2002) Afar: insecurity and delayed rains threaten livestock and people. Emergencies Unit for Ethiopia (UN-EUE). Addis Ababa.

30. Cunningham AB (1996) People, park and plants use: recommendations for multiple use zones and development alternatives around Bwindi: Impenetrable National Park, Uganda. In: People and plants working paper 4: 18-25.

31. Gebeyehu G, Asfaw Z, Enyewu A, Raja N (2014) An ethnobotanical study of traditional medicinal plants and their conservation status in Mecha Woreda, West Gojjam Zone of Ethiopia. Int J Phram H Care Res 2: 137-154.

32. Mengesha GG (2016) Ethnobotanical survey of medicinal plants used in treating human and livestock health problems in Mandura Woreda of Benishangul Gumuz, Ethiopia. Adv Med Plant Res 4: 11-26.

\section{Acknowledgement}

Authors acknowledged the local communities of Afar and Oromo Ethnic groups living around the park for sharing of their indigenous knowledge. We also acknowledged Samara University for financial support. Finally, we appreciated two anonymous reviewers for their valuable comments to improve the manuscript quality. 